\title{
Tropical maize selection indexes genotypes for efficiency in use of nutrients: phosphorus ${ }^{1}$
}

\author{
Gabriel Gonçalves dos Reis ${ }^{2}$, Felipe Bermudez Pereira ${ }^{3 *}$, Italo Stefanine Correia Granato², \\ Júlio César DoVale ${ }^{4}$ Roberto Fritsche-Neto ${ }^{3}$
}

10.1590/0034-737X201764030007

\begin{abstract}
Brazil generates an annual demand for more than 2.83 million tons of phosphate fertilizers. Part of this is due to low P use efficiency (PUE) by plants, particularly in current maize cultivars. Thus, the aim of this study was to create indexes that allow accurate selection of maize genotypes with high PUE under conditions of either low or high P availability. The experiment was conducted in a greenhouse $\left(20^{\circ} 45^{\prime} 14^{\prime \prime} \mathrm{S} ; 42^{\circ} 52^{\prime} 53^{\prime \prime} \mathrm{W}\right)$ at the Universidade Federal de Viçosa in October 2010. We evaluated 39 experimental hybrid combinations and 14 maize inbred lines with divergent PUE under two conditions of $\mathrm{P}$ availability. The relative importance of the traits studied was analyzed and estimated by principal component analysis, factor analysis, and establishment of selection indexes. To obtain genotypes responsive to high $\mathrm{P}$

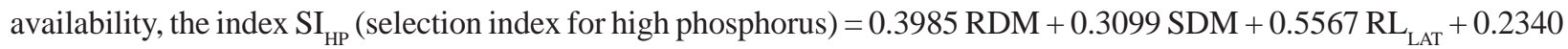
$\mathrm{PUEb}-0.1139 \mathrm{SRS}$ is recommended. To obtain genotypes tolerant to low P availability, the index $\mathrm{SI}_{\mathrm{LP}}$ (selection index for low phosphorus $)=0.3548 \mathrm{RDM}+0.3996 \mathrm{RL}_{\mathrm{LAT}}+0.3344 \mathrm{SDM}+0.0041 \mathrm{SH} / \mathrm{RS}-0.1019 \mathrm{SRS}$ is suggested.
\end{abstract}

Key words: abiotic stress; Zea mays; plant breeding; early selection.

\section{RESUMO}

\section{Índices de seleção de genótipos de milho tropical para eficiência no uso de nutrientes: fósforo}

O Brasil apresenta uma demanda anual de mais de 2,83 milhões de toneladas de fertilizantes fosfatados. Parte disto se deve a baixa eficiência no uso do fósforo (EUP) pelas plantas, especialmente nos atuais cultivares de milho. Assim, objetivou-se foi elaborar índices que permitam a seleção acurada de genótipos de milho eficientes no uso de $\mathrm{P}$ para condições de baixa e alta disponibilidade deste nutriente. O experimento foi conduzido em casa de vegetação ( $20^{\circ} 45^{\prime} 14^{\prime \prime} \mathrm{S}$; 4252'53"W), na Universidade Federal de Viçosa, em outubro de 2010. Foram avaliadas 39 combinações híbridas experimentais e 14 linhagens de milho, divergentes para a eficiência no uso de P, em duas condições de disponibilidade deste nutriente. Foi realizada a análise de importância relativa dos caracteres estudados, estimada por meio do método dos componentes principais, a análise de fatores e confecção dos índices de seleção. Para obtenção de genótipos responsivos a alta disponibilidade de fósforo é recomendado o índice $\mathrm{IS}_{\mathrm{AP}}=0,3985 \mathrm{MRS}+0,3099 \mathrm{MPS}+0,5567 \mathrm{CR}_{\mathrm{LAT}}+0,2340 \mathrm{EAbP}$ - 0,1139 SER. Para obtenção de genótipos tolerantes a baixa disponibilidade deste nutriente é sugerido o índice IS $_{\mathrm{BP}}=$ $0,3548 \mathrm{MRS}+0,3996 \mathrm{CR}_{\mathrm{LAT}}+0,3344 \mathrm{MSP}+0,0041 \mathrm{PA} / \mathrm{SR}-0,1019 \mathrm{SER}$.

Palavras-chave: estresse abiótico; Zea mays; melhoramento; seleção precoce.

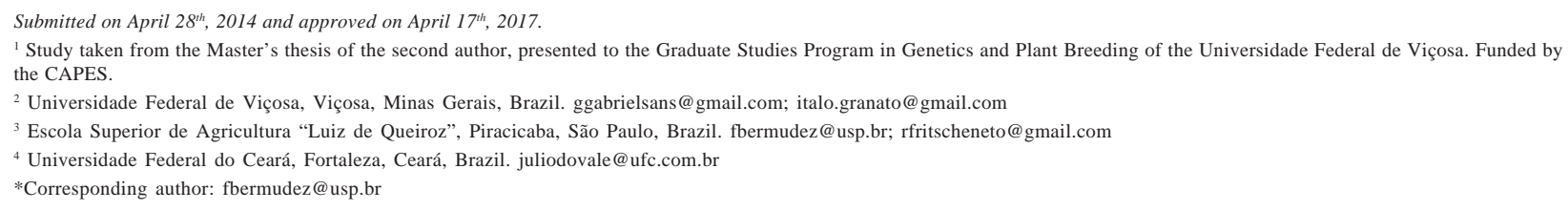




\section{INTRODUCTION}

Brazil generates an annual internal demand for more than 2.83 million tons of phosphate fertilizers. Approximately half of this amount is produced internally; the other half is imported from countries such as Russia, Morocco, China, and the United States (Vilar, 2010). Indicators show that this dependency will continue to increase sharply if new alternatives are not developed and implemented.

Part of this problem is due to low phosphorus use efficiency (PUE) by plants, particularly in current maize cultivars. This is because most of these were obtained under optimal phosphorus $(\mathrm{P})$ availability conditions; in other words, they were selected for ideal growing conditions (Cecarelli, 1996). This situation contributes to yields that do not achieve their potential.

Knowledge of the biological and functional relationships among various measurable attributes allows a more detailed choice of the traits used in making selection (Acquaah et al., 1992). Thus, traits related to the shoot and root system, together with P uptake and use efficiency, can assist in early evaluation or indirect selection methods for higher PUE through speeding the selection process and disregarding less efficient genotypes at an earlier time, concentrating resources on potentially better genotypes (Fritsche-Neto et al., 2010; Machado et al., 2004).

Knowing these relationships, the next step is to use tools that assist in establishing selection indexes. For Cruz \& Carneiro (2006), factor analysis is a significant alternative because it structures and simplifies the original data so that a large number of variables comes to be represented by a smaller number, expressed by linear combinations of these original data, called factors. Traits grouped in one factor are intensely correlated with each other and weakly correlated with other factors.

These factors are extracted by principal component analysis, whose function is to simplify a set of $n$ variables into factors with the ability of joining the maximum amount of original variation available, while remaining mutually independent (Cruz \& Carneiro, 2006). The result of factor analysis, combined with principal component analysis, allows the traits that less discriminate the genotypes to be disregarded, and then selection indexes can be established (DoVale et al., 2011).

Consequently, the aim of this study was to develop indexes that allow accurate selection of maize genotypes that have high PUE under either low or high $P$ availability.

\section{MATERIALS AND METHODS}

The experiment was conducted in a greenhouse at the Diogo Alves de Mello Experimental Field (2045'14"S; $\left.42^{\circ} 52^{\prime} 53^{\prime \prime} \mathrm{W}\right)$ that belongs to the Plant Science Department of the Universidade Federal de Viçosa, Brazil, in October 2010. We used 39 experimental hybrid combinations of maize and their 14 parent inbred lines that came from the germplasm bank of the Programa Milho ${ }^{\circledR}$. These inbred lines and hybrids have wide genetic variability for PUE, detected in previous studies (Fritsche-Neto, 2011; DoVale et al., 2013). These genotypes were then evaluated under two contrasting conditions in regard to $\mathrm{P}$ availability. Therefore, a completely randomized experimental design was used, with two replications, in a simple factorial arrangement (53 genotypes x 2 P levels). Plots consisted of one plant per pot. Although the hybrids were obtained by partial diallel crosses, the data were not evaluated considering this genetic design. The aim of this study was not to evaluate genetic control, but rather to study the possibility of indirect selection for PUE in tropical maize.

The seeds were sterilized and then germinated in polyethylene trays in individual cells. After emergence, a seedling from each genotype was transplanted in 4 $\mathrm{dm}^{3}$ cylindrical PVC pots. The experiment substrate was prepared by mixing $50 \%$ washed sand, $37.5 \%$ vermiculite, and $12.5 \%$ soil (from the B horizon of a Latossolo Vermelho-Amarelo Distrófico). The soil was used to adsorb the $\mathrm{P}$ and not leave it immediately available to the plants.

$\mathrm{P}$ was added in the form of triple superphosphate. For the high $\mathrm{P}$ availability condition (HP), $192 \mathrm{mg}$ of $\mathrm{P} \mathrm{dm}^{-3}$ was mixed in the substrate, and in the low $\mathrm{P}$ condition (LP), 34 $\mathrm{mg} \mathrm{dm}^{-3}$. The other nutrients were supplied via modified Hoagland \& Arnon (1938) nutrient solution, without addition of $\mathrm{P}$.

After collection of the plants in the six fully-expanded leaf vegetative stage (V6), the shoots were separated from the roots. The traits measured were shoot dry matter (SDM), root dry matter $(\mathrm{RDM})$, lateral root length $\left(\mathrm{RL}_{\mathrm{LAT}}\right)$, axial root length $\left(\mathrm{RL}_{\mathrm{AXI}}\right)$, lateral root surface area $\left(\mathrm{SA}_{\mathrm{LAT}}\right)$, and axial root surface area $\left(\mathrm{SA}_{\mathrm{AXI}}\right)$. The weight of the dry shoots and roots were determined after drying in a forced air circulation laboratory oven for 72 hours at $60^{\circ} \mathrm{C}$.

The root lengths and areas were obtained through image analysis using WinRhizo PRO 2009c, coupled to the Epson Expression XL 10000 professional scanner equipped with a transparency unit (TPU), as described by Bouma et al. (2000); for this purpose, the entire root was used and not only samples. Roots with diameter less than or equal to $0.5 \mathrm{~mm}$ were considered lateral roots, and those with diameters greater than $0.5 \mathrm{~mm}$ as axial roots (Trachsel et al., 2009). From these values, the specific root surface area (SRS) and the ratio between the shoot dry matter and the root surface area (SDM/RS) were obtained by the following expressions: 
$\mathrm{SRS}=\frac{\mathrm{SA}_{\mathrm{LAT}}+\mathrm{SA}_{\mathrm{AXI}}}{\mathrm{RDM}}$ and $\mathrm{SDM} / \mathrm{RS}=\frac{\mathrm{RDM}}{\mathrm{SA}_{\mathrm{LAT}}+\mathrm{SA}_{\mathrm{AXI}}}$,

in which RDM is the root dry matter and SDM is the shoot dry matter.

To calculate $\mathrm{P}$ concentration, a $0.1 \mathrm{~g}$ sample was taken, and nitric perchloric acid digestion was performed according to Malavolta et al. (1989), and then reading of $\mathrm{P}$ concentration in a spectrophotometer at $725 \mathrm{~nm}$.

The nutritional efficiency indexes were obtained as described by Moll et al. (1982) in $\mathrm{mg} \mathrm{mg}^{-1}$, $\mathrm{PUEb}=\frac{\mathrm{P}_{(\mathrm{PLANT})}}{\mathrm{P}_{(\text {APPLIED })}} \quad, \quad \mathrm{PUEt}=\frac{\mathrm{SDM}}{\mathrm{P}_{(\mathrm{PLANT})}} \quad$ and PUE $=\frac{\text { SDM }}{\mathrm{P}_{(\text {APPLIED })}}=$ PUEt $x$ PUEb in which $\mathrm{P}_{(\text {PLANT })}$ is the phosphorus present in the photosynthetically active plant tissues and $\mathrm{P}_{\text {(APPLIED), }}$ the phosphorus applied in the substrate used in this study.

After obtaining the data, the following model was used for analyses of variance: $Y_{i j k}=\mu+a_{i}+\beta_{j}+(a \beta) i j+\varepsilon_{i j k}$, in which $Y_{i j k}$ is the value observed for the trait in the $i$-th genotype, $j$-th level (P availability) and $k$-th replication; $\mu$ is the overall mean for the trait; $\dot{a}_{i}$ is the effect of the $i$-th genotype $(i=1,2,3, \ldots, 53)$, considered as a random effect because it is a population sample with wide genetic variability for PUE (Fritsche-Neto, 2011; DoVale et al., 2013), in which $g \sim \mathrm{NID}\left(0, \sigma_{p}^{2}\right) ; \hat{a}_{j}$ is the effect of the $j$-th application rate of the nutrient $(j=1,2)$, considered as a fixed effect, in which $a \sim \mathrm{N}\left(\mathrm{a}, \mathrm{a}^{2}\right) ;(a \hat{a})_{i j}$ is the interaction effect of the $i$-th genotype with $j$-th application rate of the nutrient, considered as random effect, in which $g a \sim \operatorname{NID}\left(0, \sigma_{g \times a}^{2}\right)$; and $\varepsilon_{i k}$ is the effect of the random error associated with the observation of order $i j k$, in which $\sim \operatorname{NID}\left(0, \sigma^{2}\right)$.

The estimates of phenotypic correlations $\left(r_{f}\right)$ were obtained through the Pearson coefficient:

$r_{f}=\frac{\sum\left(\mathrm{x}_{\mathrm{i}}-\mathrm{x}\right)\left(\mathrm{y}_{\mathrm{i}}-\mathrm{y}\right)}{\sqrt{\sum\left(\mathrm{x}_{\mathrm{i}}-\mathrm{x}\right)^{2}\left(\mathrm{y}_{\mathrm{i}}-\mathrm{y}\right)^{2}}}$, in which $\mathrm{x}_{1}, \mathrm{x}_{2}, \ldots, \mathrm{x}_{\mathrm{n}}$ and $\mathrm{y}_{1}, \mathrm{y}_{2}, \ldots$, $\mathrm{y}_{\mathrm{n}}$ and are the values observed for the traits measured. The estimates of $r_{f}$ were tested at $1 \%$ and $5 \%$ probability by the $t$ test.

The relative importance of the traits studied was estimated by principal component analysis (Singh, 1981). The traits that least contributed to genetic divergence among the genotypes were chosen for elimination. Therefore, to construct the selection index, the characters with the highest weighted values in the smallest eigen values component were ignored.

After that, the following model was used to perform factor analyses: $x_{j}=l_{j I} F_{1}+l_{j 2} F_{2}+\ldots+l_{j m} F_{m}$, in which $X_{j}$ is the estimated variable in each plot, with $j=1,2, \ldots \mathrm{v}, l j k$ is the factor loading for the $j$-th variable associated with the $k$-th factor, with $k=1,2, \ldots \mathrm{m}, F_{k}$ is the $\mathrm{k}$-th common factor, and $a_{i}$ is the specific factor associated with the $i$-th variable. The initial factor loading is given by: $l_{j k}=\lambda_{i j}^{2} V_{i j}^{2}$, in which $\lambda_{i j}$ is the $i$-th eigenvalue greater than 1 obtained from the matrix of phenotypic correlations, and $V_{i j}$ is the $j$ th value of the $i$-th vector, with $j$ being the number of variables and $k$ the number of factors. Communality is represented by: $C_{j}=l^{2}{ }_{j 1}+l^{2}{ }_{j 2}+\ldots+l^{2}{ }_{j m}$. The number of final factors considered for grouping traits was given by the number of eigenvalues greater than or equal to 1.00 . Traits were grouped based on the final factor loadings greater than 0.70 obtained after rotation, which indicates that these traits have high correlation and can be grouped in a single factor. Factor loadings were extracted by principal component analysis, and the factors were established by the varimax rotation method (Cruz \& Carneiro, 2006).

The scores used in creating the indexes were obtained through the following equation system: $F_{k}=b_{1 k} x_{1}+b_{2 k} x_{2}$ $+\ldots+b_{v k} x_{v}$, with $b j k(k=1,2, \ldots \mathrm{m}, j=1,2 \ldots \mathrm{v})$ being the element of matrix $\beta$, given by: $\beta=\left(\Lambda^{\prime} \Lambda\right)^{-1} \Lambda^{\prime}$, in which $E$ is the $\mathrm{m} \times \mathrm{v}$ dimension matrix of the final rotated factor loadings, and $\beta$ is the $\mathrm{m} \times \mathrm{v}$ dimension matrix of the weighted coefficients of the traits for obtaining the scores of the factors.

Analysis of the relative importance of the traits studied, estimated by principal component analysis, factor analysis, and establishment of the selection indexes, was carried out according to DoVale et al. (2011). All of them were performed using the genetics and statistics computer application GENES (Cruz, 2013).

\section{RESULTS AND DISCUSSION}

According to combined analysis of variance, the different $P$ availabilities used were sufficient to differentiate the genotypes in regard to the main variable (PUE) and other attributes, with the exception of PUEt and SH/RS (Table 1). However, only PUE, $\mathrm{RL}_{\mathrm{AXI}}$, SDM, and RDM had differentiated responses in the two environments tested, confirmed by the significance of the genotype x P levels ( $G$ x P) interaction. Similar results were observed by DoVale \& Fritsche-Neto (2013), Pereira et al., (2013), Fritsche-Neto (2011), and Souza et al., (2009). The values of the experimental coefficients of variation were within acceptable levels for studies of this nature, that is, under stress conditions, which indicated good experimental precision (Pereira et al., 2013; DoVale et al., 2011; Fritsche-Neto et al., 2010).

In the attempt to identify QTL for PUE, Chen et al. (2009) were not successful in mapping regions of the genome with genes coinciding for contrasting conditions of $\mathrm{P}$ availability. That is because the genes are expressed differentially in accordance with the environment (Souza et al., 2009). Thus, this justifies making selection in specific environments and not in accordance with mean behavior. 
Table 1: Summary of the simple analyses of variance for the traits shoot dry matter (SDM), root dry matter (RDM), specific root area (SRA), shoot/root surface ratio (SH/RS), lateral root length $\left(\mathrm{RL}_{\mathrm{LAT}}\right)$, axial root length $\left(\mathrm{RL}_{\mathrm{AXI}}\right)$, lateral root surface area $\left(\mathrm{SA}_{\mathrm{LAT}}\right)$, axial root surface area $\left(\mathrm{SA}_{\mathrm{AXI}}\right)$, phosphorus uptake efficiency (PUEb), phosphorus utilization efficiency (PUEt), and phosphorus use efficiency (PUE) of 39 experimental hybrid combinations and 14 parent inbred lines of tropical maize, evaluated at high and low phosphorus availability, Viçosa, MG, Brazil, 2010

Good phosphorus availability

\begin{tabular}{|c|c|c|c|c|c|c|c|c|c|c|c|c|}
\hline \multirow[t]{2}{*}{ SV } & \multirow[t]{2}{*}{ DF } & \multicolumn{11}{|c|}{ Mean Square } \\
\hline & & SDM & RDM & SRA & SH/RS & $\mathbf{R L}_{\mathrm{LAT}}$ & $\mathbf{R L}_{\mathrm{AXI}}$ & $\mathbf{S A}_{\mathrm{LAT}}$ & $\mathbf{S A}_{\mathrm{AXI}}$ & PUEb & PUEt & PUE \\
\hline Genotype & 52 & $1.42 * *$ & $0.06^{* *}$ & $2 \mathrm{E}-4 *$ & $1.24^{\text {N.S. }}$ & $109.85^{* *}$ & $18.26^{* *}$ & $4 \mathrm{E}-5 * *$ & $3 \times 10^{-4 * *}$ & $8 \mathrm{E}-5^{* *}$ & $2 \mathrm{E} 4^{\text {N.S. }}$ & $2.41 * *$ \\
\hline Residue & 52 & 0.23 & 0.01 & $1 \mathrm{E}-4$ & 1.11 & 27.38 & 2.56 & $1 \mathrm{E}-5$ & $3 \mathrm{E}-5$ & $3 \mathrm{E}-5$ & $2 \mathrm{E} 4$ & 0.40 \\
\hline $\mathrm{CV}(\%)$ & & 22.88 & 19.97 & 10.17 & 25.07 & 19.44 & 15.47 & 19.56 & 16.41 & 31.86 & 26.95 & 22.88 \\
\hline Mean & & 2.12 & 0.51 & 0.11 & 4.21 & 26.92 & 10.35 & 0.02 & 0.04 & 0.02 & 180.40 & 2.76 \\
\hline$h^{2}$ & & 0.83 & 0.84 & 0.48 & 0.11 & 0.75 & 0.86 & 0.74 & 0.87 & 0.68 & -0.13 & 0.83 \\
\hline \multirow{3}{*}{ SV } & & \multicolumn{11}{|c|}{ Low phosphorus availability } \\
\hline & DF & \multicolumn{11}{|c|}{ Mean Square } \\
\hline & & SDM & RDM & SRA & SH/RS & $\mathbf{R L}_{\mathrm{LAT}}$ & $\mathbf{R L}_{\mathrm{AXI}}$ & $\mathbf{S A}_{\text {LAT }}$ & $\mathbf{S A}_{\mathrm{AXI}}$ & PUEb & PUEt & PUE \\
\hline Genotype & 52 & $0.26^{* *}$ & $0.06 * *$ & $2 \mathrm{E}-4 *$ & $0.21 * *$ & $124.92 * *$ & $20.07 * *$ & $5 \mathrm{E}-5 * *$ & $2 \mathrm{E}-4 * *$ & $7 \mathrm{E}-5 * *$ & $1 \mathrm{E} 5 * *$ & $14.36 * *$ \\
\hline Residue & 52 & 0.08 & 0.01 & $9 \mathrm{E}-5$ & 0.10 & 21.68 & 3.89 & $1 \mathrm{E}-5$ & $5 \mathrm{E}-5$ & $5 \mathrm{E}-5$ & $9 \mathrm{E} 4$ & 4.51 \\
\hline $\mathrm{CV}(\%)$ & & 29.16 & 20.74 & 9.00 & 17.17 & 15.07 & 18.25 & 15.21 & 21.13 & 45.45 & 18.15 & 29.16 \\
\hline Mean & & 0.98 & 0.53 & 0.10 & 1.84 & 30.90 & 10.80 & 0.02 & 0.03 & 0.01 & 510.26 & 7.28 \\
\hline$h^{2}$ & & 0.69 & 0.79 & 0.61 & 0.53 & 0.83 & 0.81 & 0.82 & 0.78 & 0.40 & 0.26 & 0.69 \\
\hline
\end{tabular}

*,**: significant at $5 \%$ and $1 \%$ probability, respectively, by the $\mathrm{F}$ test.

Table 2: Summary of the combined analyses of variance evaluated under contrasting conditions of phosphorus availability for the traits shoot dry matter (SDM), root dry matter (RDM), specific root area (SRA), shoot/root surface ratio ( $\mathrm{SH} / \mathrm{RS})$, lateral root length $\left(\mathrm{RL}_{\mathrm{LAT}}\right)$, axial root length $\left(\mathrm{RL}_{\mathrm{AXI}}\right)$, lateral root surface area $\left(\mathrm{SA}_{\mathrm{LAT}}\right)$, axial root surface area $\left(\mathrm{SA}_{\mathrm{AXI}}\right)$, phosphorus uptake efficiency (PUEb), phosphorus utilization efficiency (PUEt), and phosphorus use efficiency (PUE) of 39 experimental hybrid combinations and 14 inbred lines of maize, Viçosa, MG, Brazil, 2010

\begin{tabular}{|c|c|c|c|c|c|c|c|c|c|c|c|c|}
\hline \multirow{2}{*}{ SV } & \multirow{2}{*}{ DF } & \multicolumn{11}{|c|}{ Mean Square } \\
\hline & & SDM & RDM & SRA & SH/RS & $\mathbf{R L}_{\mathrm{LAT}}$ & $\mathbf{R L}_{\mathrm{AXI}}$ & $\mathbf{S A}_{\mathrm{LAT}}$ & $\mathbf{S A}_{\mathrm{AXI}}$ & PUEb & PUEt & PUE \\
\hline Genotype (G) & 52 & $1.27 * *$ & $0.11 * *$ & $3 \mathrm{E}-4 * *$ & $0.75^{\text {N.S. }}$ & $206.32 * *$ & $33.72 * *$ & $8 \mathrm{E}-5^{* *}$ & $4 \mathrm{E}-4 * *$ & $1 \mathrm{E}-3 * *$ & 3 E3 ${ }^{\text {N.S. }}$ & $12.89^{* *}$ \\
\hline P Levels (P) & 1 & $66.94 * *$ & $0.02^{\mathrm{N} . \mathrm{S}}$ & 3 E-4 N.S. & $284.44 * *$ & $681.35^{* *}$ & $6.33^{\text {N.S. }}$ & 4 E-4 ** & $1 \mathrm{E}-4^{\text {N.S. }}$ & 7 E-5 N.S. & $5 \mathrm{E} 6 * *$ & $990.45^{* *}$ \\
\hline$G \times P$ & 52 & $0.37 * *$ & $0.02 *$ & $1 \mathrm{E}-4^{\text {N.S. }}$ & $0.69^{\text {N.S. }}$ & $32.86^{\text {N.S. }}$ & $5.12 *$ & $1 \mathrm{E}-6^{\text {N.S. }}$ & 6 E-5 N.S. & 3 E-5 N.S. & 8 E3 N.S. & $4.24 * *$ \\
\hline Residue & 104 & 0.16 & 0.01 & $1 \mathrm{E}-4$ & 0.62 & 24.59 & 3.21 & $1 \mathrm{E}-5$ & 4 E-5 & 3 E-5 & $5 \mathrm{E} 3$ & 2.41 \\
\hline Mean & & 1.56 & 0.52 & 0.10 & 3.04 & 28.89 & 10.58 & 0.02 & 0.03 & 0.02 & 343.75 & 5.00 \\
\hline $\mathrm{CV}(\%)$ & & 25.72 & 20.37 & 9.63 & 25.87 & 17.17 & 16.95 & 17.25 & 18.79 & 38.68 & 21.40 & 31.07 \\
\hline
\end{tabular}


The results of individual analysis of variance indicated that, under low $\mathrm{P}$ availability, there was a significant difference for genotype effect in all the traits measured (Table 2). The same occurred at a high supply of this nutrient, except for the SH/RS ratio and the PUEt. The heritability values of these two traits were lower in this environment. These genetic differences observed at each level of P indicate genotypic variability. This confirms that gains from selection can be obtained. As there was a higher number of traits with different performances in low $\mathrm{P}$, it can be affirmed that the state of P nutritional stress increases the amplitude of morphological and physiological differences tested in topical maize genotypes, which allows greater exploitation of genetic variability.

Under nutritional stress, the genes that codify high affinity $\mathrm{P}$ transporters in the roots have preferential expression. Some of these gene inductions are directly involved in increasing $\mathrm{P}$ availability in the rhizosphere and in promoting $\mathrm{P}$ uptake (Raghothama, 2000). Yet under high supply of inorganic $\mathrm{P}(\mathrm{Pi})$, a variable amount of this element is lost by the cell via efflux (Rausch \& Bucher, 2002). Thus, combining reduction or elimination of efflux with a greater amount of active $\mathrm{P}$ transporters in the roots, efficiency in the use of $\mathrm{P}$ tends to be greater in the stress environment. This can be seen upon comparing the PUE in the two environments; at low $\mathrm{P}$, the response was 2.6 times greater than at the other level.

In both environments, most of the traits had significant and high magnitude correlation with the main variable (PUE) under study (Table 3). According to Cruz et al., (2012), selection based on one or a few characteristics proves to

Table 3: Coefficients of Pearson phenotypic correlations $\left(r_{f}\right)$ among traits of the 39 experimental hybrid combinations and 14 maize inbred lines evaluated at high and low phosphorus availability, Viçosa, MG, Brazil, 2010

\begin{tabular}{lcc}
\hline & \multicolumn{2}{c}{ PUE } \\
\cline { 2 - 3 } & Low P & High P \\
\hline SDM & $1.00^{* *}$ & $1.00^{* *}$ \\
RDM & $0.84^{* *}$ & $0.83^{* *}$ \\
SRA & $-0.36^{* *}$ & $-0.48^{* *}$ \\
SH/RS & $0.48^{* *}$ & $0.45^{* *}$ \\
RL $_{\text {LAT }}$ & $0.76^{* *}$ & $0.71^{* *}$ \\
RL $_{\text {AXI }}$ & $0.84^{* *}$ & $0.83^{* *}$ \\
SA $_{\text {LAT }}$ & $0.77^{* *}$ & $0.71^{* *}$ \\
SA $_{\text {AXI }}$ & $0.86^{* *}$ & $0.85^{* *}$ \\
PUEb $_{\text {PUEt }}$ & $0.90^{* *}$ & $0.87^{* *}$ \\
\hline
\end{tabular}

**: significant at $1 \%$ probability, N.S.: non-significant, respectively, by the $\mathrm{t}$ test.

SDM - shoot dry matter; RDM - root dry matter; SRA - specific root area; $\mathrm{SH} / \mathrm{RS}$ - shoot/root surface ratio; $\mathrm{RL}_{\mathrm{LAT}}$ - lateral root length; $\mathrm{RL}_{\mathrm{AXI}}$ - axial root length; $\mathrm{SA}_{\mathrm{LAT}}$ - lateral root surface area; $\mathrm{SA}_{\mathrm{AXI}}$ - axial root surface area; PUEb - phosphorus uptake efficiency; PUEt - phosphorus utilization efficiency. be inadequate. In fact, simultaneous selection of a set of traits strongly correlated with the main variable and that are easily measurable increases the chance of success of a breeding program.

The significant correlation, though in a negative manner, of the SRS with the PUE can be explained by the fact of $\mathrm{P}$ being an element that is most taken up by plant roots through diffusion, assisted by the process of root interception (Novais et al., 2007). Thus, roots with smaller specific surfaces, that is, less area per weight unit, have greater contact and reactivity with the soil solution and clay minerals, allowing greater uptake of the element, which contributes to an increase in $\mathrm{P}$ use efficiency. This demonstrates the importance of SRS in composition of the index.

Of the PUE components proposed by Moll et al., (1982), only uptake efficiency (PUEb) is relevant in the selection process for the purpose of this study, given the nonsignificant correlation of $\mathrm{P}$ utilization efficiency (PUEt) with PUE. Similar results were found by Parentoni \& Souza Júnior (2008) in which, according to these authors, upon using selection indexes in maize aiming to increase PUE, higher weights must be given to the PUEb.

In principal component analysis, the percentage of variance accumulated in the first three factors within the stress environment was $96.40 \%$, whereas in the environment under ideal conditions of $\mathrm{P}$ availability, it was $78.86 \%$ (Table 4). Both values represent reliability for interpretation of the data with accuracy (Nascimento et al., 2009; Johnson \& Wichern, 1999). Thus, observing the analysis of the last eigenvectors, that is, from the last up to that in which the value of the eigenvector obtained in the correlation matrix is less than 0.7 , the traits $\mathrm{RL}_{\mathrm{AXI}}$ in high $\mathrm{P}$, and PUE and SDM in low P were identified as traits that could be disregarded.

Rejecting $\mathrm{RL}_{\mathrm{AXI}}$ because of high correlation with $\mathrm{RL}_{\mathrm{LAT}}$ in high and low P availability environments is justified, due to the hierarchical level between these roots described by DoVale et al., (2013). In other words, as the length of the axial roots increases, the insertion points and emergence of the lateral roots increase. The SDM, however, should not be disregarded, because it is easy to measure and represents the photosynthetically active surface of the plant, which contributes to a positive overall carbon balance, stimulating better distribution in the root system (Mollier \& Pellerin, 1999). Optimization in carbon allocation in plant roots for the purpose of greater acquisition of phosphorus is of obvious importance for adaptation of the genotypes under conditions of high and low $\mathrm{P}$ availability (Zhu et al., 2005). Among other factors, the mobility of this element is low in tropical soils, whose diffusion coefficient has a magnitude of $10^{-11} \mathrm{~cm}^{2} \mathrm{~s}^{-1}$, whereas $\mathrm{NO}_{3}^{-}$and $\mathrm{NH}_{4}^{+}$have values in the order of $10^{-6}$ 
and $10^{-7} \mathrm{~cm}^{2} \mathrm{~s}^{-1}$ (Marschner \& Marschner, 2012; Novais et al., 2007).

Through factor analysis, we sought to obtain the terms related to the traits that constitute efficiency in phosphorus use under conditions of high and low P availability (Table 5). Thus, the first three eigenvectors prevailed for grouping of traits under both conditions of $\mathrm{P}$ availability, because they concentrated most of the total variation (Table 4). The lowest communality found was 0.96 . According to Souza (1988), values as low as 0.64 are acceptable. Thus, the high efficiency of representation of the variables by a common part is evident. Consequently, discrimination of the genotypes through groups of traits formed by this analysis proved to be adequate.

According to the signals and values of the initial and final factor loadings in the three-dimensional space formed by an axis of each eigenvalue, 5 groups of traits were formed in the two environments. The correlation between the variables within the groups is of high magnitude; thus, it is admissible to disregard traits that are more difficult to measure, redundant, inadequate for discrimination of genotypes, and those that allow selection based on greater anatomical and physiological amplitude of activity in PUE. Thus, in the environment without nutritional stress, the following are disregarded: $\mathrm{SA}_{\mathrm{AXI}}$ (group 1), PUE (group 2), and $\mathrm{SA}_{\mathrm{LAT}}$ (group 3). At low P availability, the following traits should be rejected: $\mathrm{RL}_{\mathrm{AXI}}$ and $\mathrm{SA}_{\mathrm{AXI}}$ (group 1), $\mathrm{SA}_{\mathrm{LAT}}$ (group 2), and, finally, PUEb (group 3).

The best genotypes under each condition of $\mathrm{P}$ availability were selected based on the coefficients of weighting of traits from the scores obtained in each factor (Cruz \& Carneiro, 2006; DoVale et al., 2011). Thus, the selection indexes from the scores of factor 1 are proposed, whose weightings were most acceptable through attributing greater weights to the traits of greater importance for the PUE, as well as better discriminating the genotypes in the two environments; it can then be used in per se selection of maize inbred lines for this trait. In the absence of stress, the index recommended is $\mathrm{SI}_{\mathrm{HP}}$ (selection index for high phosphorus $)=0.3985 \mathrm{RDM}+0.3099 \mathrm{SDM}+0.5567$ $\mathrm{RL}_{\mathrm{LAT}}+0.2340 \mathrm{PUEb}-0.1139 \mathrm{SRS}$. Under the condition of low P supply, the recommended index is $\mathrm{SI}_{\mathrm{LP}}$ (selection index for low phosphorus) $=0.3548 \mathrm{RDM}+0.3996 \mathrm{RL}_{\mathrm{LAT}}+$ $0.3344 \mathrm{SDM}+0.0041 \mathrm{SH} / \mathrm{RS}-0.1019 \mathrm{SRS}$.

Diverse indexes have been proposed for combined selection; however, the use of multivariate analysis is important in the evaluation of large numbers of traits and establishing indexes, because, in addition to producing

Table 4: Estimates of the eigenvalues and of the cumulative fraction of variance explained by the principal components, obtained from the correlation matrix between traits associated with efficiency in use of water between tropical maize genotypes under low and high water availability, Viçosa, MG, Brazil, 2010

\begin{tabular}{|c|c|c|c|c|c|c|c|c|c|c|c|}
\hline \multirow{2}{*}{$\lambda_{j}$} & \multirow{2}{*}{$\lambda_{j}(\%)$} & \multicolumn{10}{|c|}{ High $P$ availability } \\
\hline & & SDM & RDM & SRA & SH/RS & $\mathbf{R L}_{\text {LAT }}$ & $\mathbf{R L}_{\mathrm{AXI}}$ & $\mathbf{S A}_{\text {LAT }}$ & $\mathbf{S A}_{\mathrm{AXI}}$ & PUEb & PUE \\
\hline 5.47 & 60.76 & 0.22 & -0.25 & 0.40 & - & -0.27 & 0.40 & -0.40 & 0.38 & -0.26 & 0.36 \\
\hline 0.82 & 69.85 & 0.15 & 0.71 & -0.05 & - & -0.30 & -0.07 & $4 \mathrm{E}-3$ & -0.10 & -0.61 & -0.03 \\
\hline 0.81 & 78.86 & 0.91 & -0.16 & -0.12 & - & 0.04 & -0.15 & -0.01 & -0.30 & 0.10 & 0.03 \\
\hline 64 & 86.01 & $2 \mathrm{E}-3$ & -0.15 & $2 \mathrm{E}-3$ & - & 0.80 & 0.00 & -0.07 & $3 \mathrm{E}-3$ & -0.57 & 3 E-3 \\
\hline 0.56 & 92.23 & 0.17 & 0.61 & 0.13 & - & 0.43 & 0.22 & -0.05 & 0.28 & 0.45 & 0.23 \\
\hline 0.33 & 95.89 & -0.15 & -0.03 & -0.38 & - & -0.02 & -0.21 & 0.06 & -0.12 & -0.03 & 0.88 \\
\hline 0.19 & 97.99 & 0.18 & -0.10 & -0.17 & - & -0.05 & 0.17 & 0.79 & 0.51 & -0.14 & 0.01 \\
\hline 0.09 & 99.02 & 0.06 & -0.01 & -0.65 & - & -0.03 & -0.18 & -0.46 & 0.54 & 0.02 & -0.21 \\
\hline 0.09 & 100.00 & -0.04 & $-1 \mathrm{E}-3$ & -0.46 & - & -3 E-3 & 0.81 & -0.05 & -0.34 & $2 \mathrm{E}-3$ & -0.06 \\
\hline \multirow{2}{*}{$\lambda_{j}$} & & \multicolumn{10}{|c|}{ Low $P$ availability } \\
\hline & $\%)$ & SDM & RDM & SRA & SH/RS & $\mathbf{R L}_{\text {LAT }}$ & $\mathbf{R L}_{\mathrm{AXI}}$ & $\mathbf{S A}_{\mathrm{LAT}}$ & $\mathbf{S A}_{\mathrm{AXI}}$ & PUEb & PUE \\
\hline 7.34 & 73.44 & 0.35 & 0.36 & -0.18 & 0.04 & 0.34 & 0.36 & 0.34 & 0.36 & 0.32 & 0.35 \\
\hline 1.69 & 90.38 & 0.17 & -0.18 & 0.54 & -4 E-3 & 0.00 & -0.11 & -3 E-3 & -0.10 & 0.26 & 0.17 \\
\hline 0.60 & 96.40 & -0.20 & -0.03 & 0.63 & -0.29 & 0.45 & 0.10 & 0.43 & 0.01 & -0.20 & -0.20 \\
\hline 0.19 & 98.26 & -0.02 & 0.19 & 0.43 & -0.11 & -0.46 & 0.44 & -0.37 & 0.47 & -0.06 & -0.02 \\
\hline 0.13 & 99.58 & -0.08 & -0.15 & 0.14 & -0.44 & -0.07 & -0.14 & -0.07 & -0.07 & 0.85 & -0.08 \\
\hline 0.02 & 99.79 & -0.53 & 0.40 & -0.17 & 0.40 & 0.12 & 0.16 & $5 \mathrm{E}-3$ & 0.02 & 0.25 & -0.53 \\
\hline 0.01 & 99.90 & 0.08 & 0.64 & 0.20 & -0.09 & 0.18 & -0.64 & -0.28 & 0.09 & -0.06 & 0.09 \\
\hline 0.01 & 99.98 & -0.02 & -0.36 & -0.07 & 0.03 & 0.64 & 0.10 & -0.62 & 0.26 & -4 E-3 & -0.03 \\
\hline $2 \mathrm{E}-3$ & 100.00 & 0.12 & 0.29 & 0.11 & -0.10 & 0.13 & 0.44 & -0.31 & -0.75 & $-2 \mathrm{E}-3$ & 0.13 \\
\hline 2 E-3 & 100.00 & -0.71 & -0.01 & $-2 \mathrm{E}-3$ & 8 E-3 & -1 E-4 & -2 E-3 & $2 \mathrm{E}-3$ & 0.01 & 0.00 & 0.71 \\
\hline
\end{tabular}

SDM - shoot dry matter; RDM - root dry matter; SRA - specific root area; SH/RS - shoot/root surface ratio; RL LAT $_{-}$lateral root length; $\mathrm{RL}_{\mathrm{AXI}}$ - axial root length; $\mathrm{SA}_{\mathrm{LAT}}$ - lateral root surface area; $\mathrm{SA}_{\mathrm{AXI}}$ - axial root surface area; PUEb - phosphorus uptake efficiency; PUE phosphorus use efficiency. 
Table 5: Communality, initial and final factor loadings, estimated in 53 tropical maize genotypes evaluated in regard to phosphorus use efficiency under two contrasting conditions of phosphorus availability, in Viçosa, MG, Brazil, 2010

\begin{tabular}{|c|c|c|c|c|c|c|c|c|}
\hline \multirow{3}{*}{ Evaluated trait } & \multicolumn{8}{|c|}{ High $P$ availability } \\
\hline & \multirow{2}{*}{ Group no. } & \multirow{2}{*}{ Communality } & \multicolumn{3}{|c|}{$\begin{array}{l}\text { Initial Loadings } \\
\text { Factors }\end{array}$} & \multicolumn{3}{|c|}{$\begin{array}{c}\text { Final Loadings } \\
\text { Factors }\end{array}$} \\
\hline & & & 1 & 2 & 3 & 1 & 2 & 3 \\
\hline Root dry matter & 1 & 0.97 & 0.97 & -0.15 & 0.09 & 0.63 & -0.53 & -0.55 \\
\hline Axial root surface area & & 0.99 & 0.96 & -0.01 & 0.04 & 0.65 & -0.38 & -0.61 \\
\hline Shoot dry matter & 2 & 0.98 & 0.97 & 0.04 & -0.21 & 0.49 & -0.31 & -0.80 \\
\hline Phosphorus use efficiency & & 0.98 & 0.97 & 0.04 & -0.21 & 0.49 & -0.31 & -0.80 \\
\hline Lateral root length & 3 & 0.98 & 0.91 & 0.23 & 0.31 & 0.88 & -0.18 & -0.42 \\
\hline Lateral root surface area & & 0.99 & 0.91 & 0.23 & 0.31 & 0.88 & -0.19 & -0.42 \\
\hline P uptake efficiency & 4 & 0.96 & 0.89 & 0.15 & -0.37 & 0.37 & -0.17 & -0.89 \\
\hline \multirow[t]{2}{*}{ Specific root surface area } & 5 & 0.99 & -0.63 & 0.76 & -0.08 & -0.18 & 0.95 & 0.22 \\
\hline & \multicolumn{8}{|c|}{ Low $P$ availability } \\
\hline Root dry matter & 1 & 0.98 & 0.97 & -0.19 & -0.04 & 0.87 & 0.03 & -0.47 \\
\hline Axial root length & & 0.96 & 0.97 & -0.09 & 0.06 & 0.92 & 0.05 & -0.34 \\
\hline Axial root surface area & & 0.96 & 0.97 & -0.08 & -0.01 & 0.89 & 0.10 & -0.39 \\
\hline Lateral root length & 2 & 0.96 & 0.92 & 0.05 & 0.33 & 0.98 & 0.02 & -0.04 \\
\hline Lateral root surface area & & 0.97 & 0.93 & 0.05 & 0.31 & 0.98 & 0.03 & -0.05 \\
\hline P uptake efficiency & 3 & 0.91 & 0.85 & 0.38 & -0.19 & 0.74 & 0.56 & -0.23 \\
\hline Shoot dry matter & & 0.99 & 0.95 & 0.25 & -0.18 & 0.82 & 0.46 & -0.33 \\
\hline Shoot/root surface ratio & 4 & 0.97 & 0.07 & 0.95 & -0.26 & 0.01 & 0.94 & 0.30 \\
\hline Specific root surface area & 5 & 0.96 & -0.50 & 0.70 & 0.47 & -0.25 & 0.25 & 0.92 \\
\hline
\end{tabular}

reliable indexes attributing weights to the most important traits, it is efficient in disregarding traits with little contribution to discrimination of genotypes. Thus, the hope is that by these indexes, it may be possible to make early selection of tropical maize genotypes with potential for utilization in breeding programs, or at least that it may be possible to disregard those genotypes hat do not show potential and allow efforts to be concentrated on those of greater prominence.

\section{CONCLUSIONS}

To obtain genotypes responsive to high availability of phosphorus, the following index is recommended: $\mathrm{SI}_{\mathrm{HP}}=0.3985 \mathrm{RDM}+0.3099 \mathrm{SDM}+$ $0.5567 \mathrm{RL}_{\mathrm{LAT}}+0.2340 \mathrm{PUEb}-0.1139 \mathrm{SRS}$.

To obtain genotypes tolerant to low availability of phosphorus, the following index is suggested: $\mathrm{SI}_{\mathrm{LP}}=0.3548 \mathrm{RDM}+0.3996 \mathrm{RL}_{\mathrm{LAT}}+0.3344 \mathrm{SDM}+$ $0.0041 \mathrm{SH} / \mathrm{RS}-0.1019 \mathrm{SRS}$.

\section{REFERENCES}

Acquaah G, Saunders JW \& Ewart LC (1992) Homeotic floral mutations. Plant Breeding Reviews, 9:63-99.

Bouma TJ, Nielsen KF \& Koutsaal BP (2000) Sample preparation and scanning protocol for computerised analysis of root length and diameter. Plant and Soil, 218:185-196.
Cecarelli S (1996) Adaptation to low/high input cultivation. Euphytica, 92:203-214

Chen J, Xu L, Cai Y \& Xu J (2009) Identification of QTLs for phosphorus utilization efficiency in maize (Zea mays L.) across P levels. Euphytica, 167:245-252.

Cruz CD \& Carneiro PCS (2006) Modelos biométricos aplicados ao melhoramento genético. Viçosa, Editora UFV. 585p.

Cruz CD, Regazzi AJ \& Carneiro PCS (2012) Modelos biométricos aplicados ao melhoramento genético. $4^{\mathrm{a}}$ ed. Viçosa, Editora UFV. 514p.

Cruz CD (2013) Genes - a software package for analysis in experimental statistics and quantitative genetics. Acta Scientiarum, $35: 271-276$

DoVale JC, Fritsche--Neto R \& Silva PSL (2011) Índice de seleção para cultivares de milho com dupla aptidão: minimilho e milho verde. Bragantia, 70:781-787.

DoVale JC, Maia C, Fritsche-Neto R, Miranda GV \& Cavatte PC (2013) Genetic responses of traits relationship to components of nitrogen and phosphorus use efficiency in maize. Acta Scientiarum Agronomy, 35:31-38.

DoVale JC \& Fritsche-Neto R (2013) Genetic control of traits associated with phosphorus use efficiency in maize by REML/ BLUP. Revista Ciência Agronômica, 44:554-563.

Fritsche-Neto R (2011) Seleção genômica ampla e novos métodos de melhoramento do milho. Tese de Doutorado. Universidade Federal de Viçosa, Viçosa. 39p.

Fritsche-Neto R, Miranda GV, Delima RO, Souza LV \& Silva J (2010) Herança de caracteres associados à eficiência de utilização do fósforo em milho. Pesquisa Agropecuária Brasileira, $45: 465-471$ 
Hoagland DR \& Arnon DI (1938) The water-culture method for growing plants without soil. Gainesville, Unviversity of Florida. 39p. (Circular, 347).

Johnson RA \& Wichern DW (1999) Applied multivariate statistical analysis. New Jersey, Prentice-Hall. 773p.

Machado CTT, Machado AT \& Furlani AMC (2004) Variação intrapopulacional em milho para características relacionadas com a eficiência de absorção e utilização de fósforo. Revista Brasileira de Milho e Sorgo, 3:77-91.

Malavolta E, Vitti GC \& Oliveira SA (1989) Avaliação do estado nutricional de plantas: princípios e aplicações. Piracicaba, Potafós. $201 \mathrm{p}$

Marschner H \& Marschner P (2012) Mineral nutrition of higher plants. 3rd edition. London, Elsevier. 643p.

Moll RH, Kamprath EJ \& Jackson WA (1982) Analysis and Interpretation of Factors Which Contribute to Efficiency of Nitrogen-Utilization. Agronomy Journal, 74:562-564.

Mollier A \& Pellerin S (1999) Maize root system growth and development as influenced by phosphorus deficiency. Jornal of Experimental Botany, 50:477-487.

Nascimento M, Cruz CD, Campana ACM, Tomaz RS, Salgado CS \& Ferreira RP (2009) Alteração no método centroide de avaliação da adaptabilidade genotípica. Pesquisa Agropecuária Brasileira, 44:263-269.

Novais RF, Smith TJ \& Nunes FN (2007) Fósforo. In: Novais RF Alvarez V VH, Barros NF, Fontes RLF, Cantarutti RB \& Neves JCL (Eds.) Fertilidade do Solo. Viçosa, SBCS. p.471-550.

Parentoni SN \& Souza Júnior CL (2008) Phosphorus acquisition and internal utilization efficiency in tropical maize genotypes. Pesquisa Agropecuária Brasileira, 43:893-901.
Pereira FB, DoVale JC, Carneiro PCS \& Fritsche-Neto R (2013) Relação entre os caracteres determinantes das eficiências no uso de nitrogênio e fósforo em milho. Revista Ceres, 60:636645 .

Raghothama KG (2000) Phosphate transport and signaling. Current Opinion in Plant Biology, 3:182-187.

Rausch C \& Bucher M (2002) Molecular mechanisms of phosphate transport in plants. Springer, 216:23-37.

Singh D (1981) The relative importance of characters affecting genetic divergence. The Indian Journal of Genetic and Plant Breeding, 41:237-241.

Souza J (1988) Métodos estatísticos nas ciências psicossociais. Brasília, Thesaurus. 525p.

Souza LV, Miranda GV, Galvão JCC, Guimarães LJM \& Santos IC (2009) Combining ability of maize grain yield under different levels of environmental stress. Pesquisa Agropecuária Brasileira, 44:1297-1303.

Trachsel S, Messmer R, Stamp P \& Hund A (2009) Mapping of QTLs for lateral and axile root growth of tropical maize. Theoretical and aplied genetics, 119:1413-1424.

Vilar CC (2010) Porque utilizamos tanto fertilizante fosfatado? Available at: <http://agrosenso.blogspot.com/2010/12/por-queutilizamos-tanto-fertilizante.html>. Accessed on: 23 May 2011.

Zhu J, Kaepler SM \& Lynch JP (2005) Topsoil foraging and phosphorus acquisition efficiency in maize (Zea mays L.). Functional Plant Biology, 32:749-762. 